\title{
EXTENDED RANGE AND FLIGHT PERIOD OF THE COMMON BUCKEYE BUTTERFLY IN SOUTHERN MANITOBA
}

PETER TAYLOR, P.O. Box 597, Pinawa, MB, ROE 1L0, E-mail: $<$ taylorp@granite.mb.ca>, LARRY DE MARCH, 467 Churchill Drive, Winnipeg, MB, R3L 1W3, E-mail: <demarchl@mts.net> and A. RICHARD WESTWOOD, Dept. of Biology, University of Winnipeg, Winnipeg, MB, R3B 2E9, E-mail: <r.westwood@uwinnipeg.ca>

\section{Introduction and Description}

This article describes a recent series of Common Buckeye, (Junonia coenia Hübner), butterfly records in Manitoba. These comprise one specimen in 1994, three specimens in 2001, and three specimens plus at least seven individuals seen in 2007. Klassen et al. summarized previous records for the province as follows: nine specimens collected at six locations on 1 to 25 July between 1930 and 1941 , plus a colony reported in Sandilands Provincial Forest in early August $1976 .^{7}$ One of the specimens, a worn female in the Royal Saskatchewan Museum (RSM), collected by J.B. Wallis at Husavik (often written Husavick), is dated 2 July 1910. Since this is one of the localities listed by Klassen et al., it is possible that "1930" is a transcription error. ${ }^{7}$ Details of all recent records (1994 to 2007) are provided in Table 1, and localities for both recent

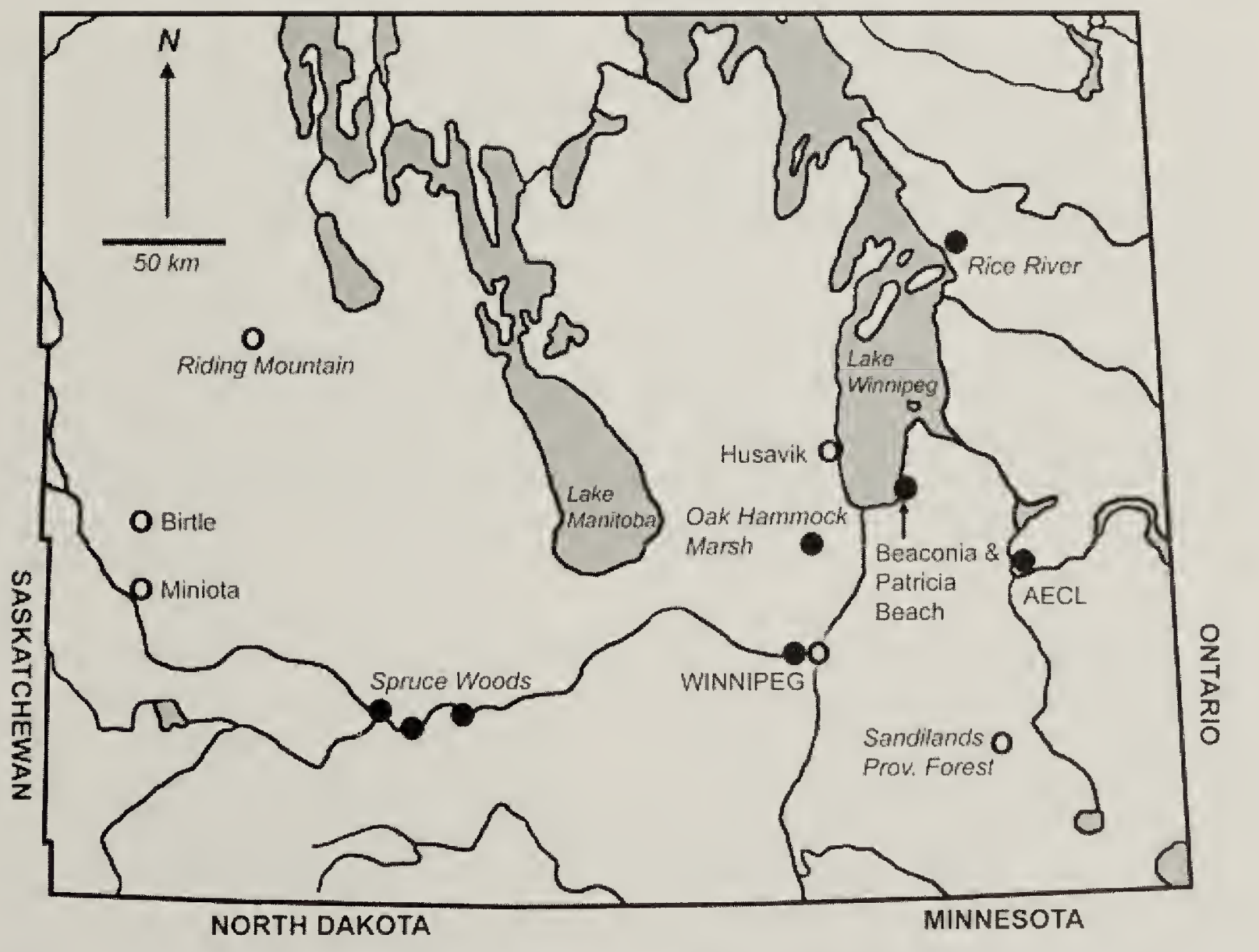

Figure 1. Map of Buckeye records for Manitoba. Open circles represent historic records (1910 to 1976); filled circles represent recent records (1994 to 2007). 


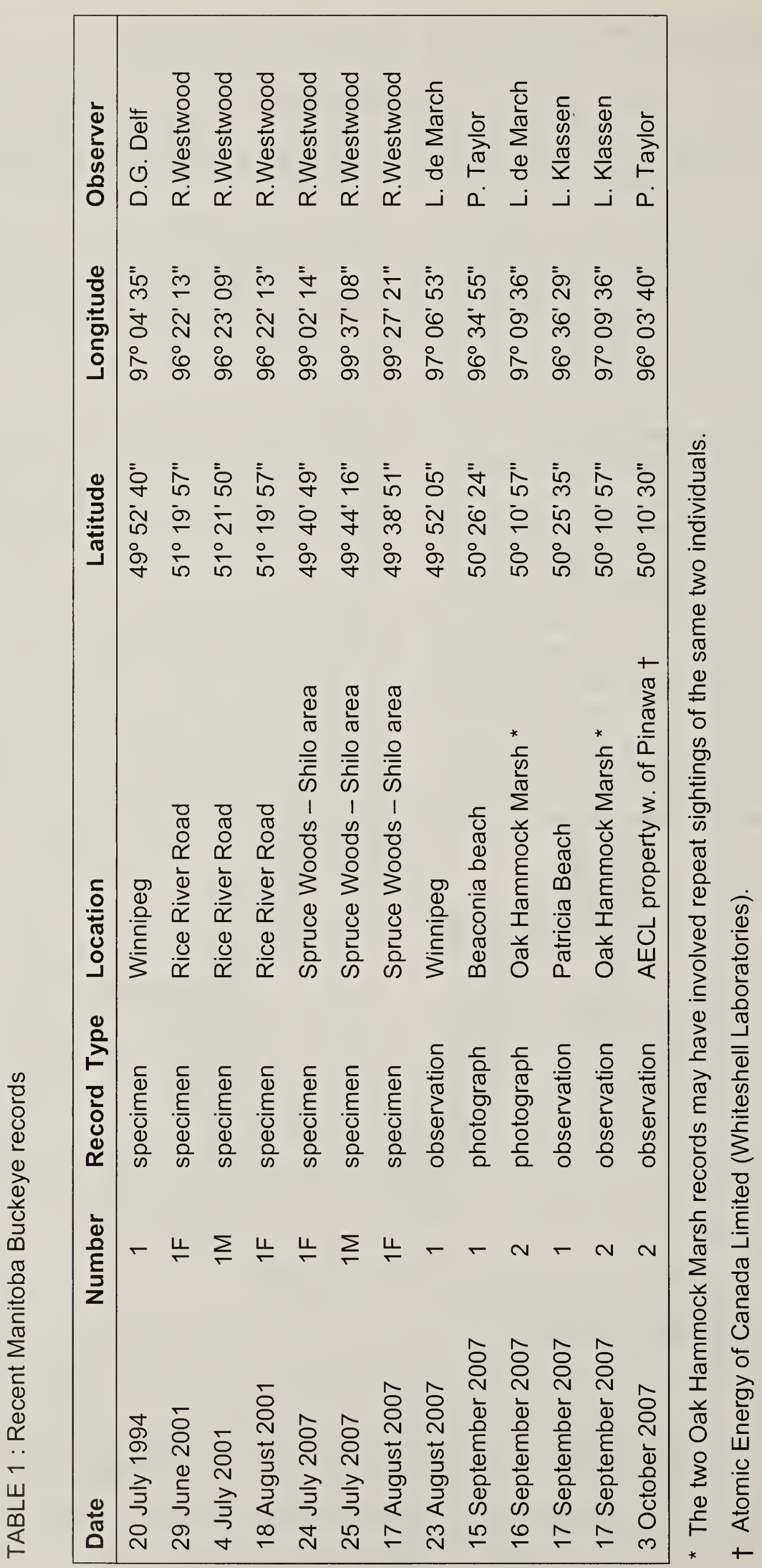


and historic records are mapped in Figure 1.

The Common Buckeye (hereafter, Buckeye) is a medium-sized nymphalid butterfly, though with considerable geographic and generational variation in size, as well as sexual dimorphism. It resembles the Red Admiral in its silhouette, rapid flight, and territorial behaviour. The primary field mark in flight is a creamy-white patch toward the tip of each forewing. At rest with wings folded above the back, a leaflike appearance is maintained (Figure 2 , on inside back cover, middle). In a dorsal basking posture, however, the butterfly displays a rich pattern of peacock-like "eyes" and orange markings, as well as the bold, creamy patches noted above (Figure 3, on inside back cover, bottom).

\section{Migration and Distribution}

Opler and Krizek classify the Buckeye as an emigratory species, characterized by irregular northward expansions, usually during late summer. ${ }^{11}$ These movements may represent either northward migratory behaviour or dispersal from areas with elevated populations. This is distinct from species such as the Monarch that perform well-defined two-way migrations. Some butterflies, for example the Red Admiral and Painted Lady, show northward movements in varying numbers in spring, with less frequently observed return flights. ${ }^{9,10}$

The Buckeye's core winter range is in the southern United States and northern Mexico. ${ }^{11}$ The northward emigratory range extends through most of the lower 48 United States, except Montana, Washington and much of Idaho and Wyoming, to parts of southern Canada. . $^{1,3,5,8,11}$ Records are sparse in many of the northern states, and most Canadian records are concentrated in southern Ontario and Quebec, northward to Manitoulin Island, Algonquin Park, and Quebec City. ${ }^{3,8}$ In states adjoining Manitoba, recent distribution maps show records for 16 of 87 Minnesota counties and 6 of 53 North Dakota counties. ${ }^{1}$ In northwestern Ontario there is an outlying record for Geraldton, east of Lake Nipigon. ${ }^{3,8}$

Ron Hooper, a long-time Saskatchewan entomologist and frequent contributor to this journal, noted some years ago that the Buckeye should be watched for in southeastern Saskatchewan as well as in southern Manitoba. ${ }^{4}$ More recently he confirmed that there are still no definite records for Saskatchewan, though the RSM has a Buckeye wing donated by a resident of Bracken in southwestern Saskatchewan, and possibly found there (R. Hooper, letter to PT).

\section{Food Plants and Habitat}

Commonly cited larval food plants belong to the plantain and figwort families (Plantaginaceae and Scrophulariaceae): ribgrass or English plantain (Plantago lanceolata), snapdragon (Antirrhinum sp.) gerardia (Gerardia sp.), and toadflax (Linaria sp.). ${ }^{1,5,7,11}$ Several of these plants are exotic to North America. As with many butterflies, preferred nectar sources for adults include various composites (Asteraceae) and dogbane (Apocynum sp.). ${ }^{11}$

Buckeyes generally prefer open areas with low vegetation and at least some areas of bare ground, e.g., roadsides, dry fields with dirt roads, open pine woods, beach dunes, and railroad tracks. ${ }^{11}$ Royer mentions their occurrence on mown lawns and 'untended lawns when plantain growth is flourishing'. ${ }^{12}$ Recent Manitoba records are consistent with these 
descriptions. Observation sites along the Rice River Road in 2001 consisted of gravel roadside clearings in mixed boreal forest dominated by Black Spruce, Jack Pine, and Trembling Aspen. Buckeye specimens found in and near Spruce Woods Provincial Park in 2007 were frequenting open, mixed prairie sites containing numerous species of flowering herbs. The Beaconia and Patricia Beach sightings were on a sandy stretch of Lake Winnipeg shoreline. The Oak Hammock Marsh records were near an artesian spring adjoining restored prairie, and the butterflies settled mainly on bare ground. Those near Pinawa were in disturbed areas near a small sewage lagoon adjoining an industrial site in mixed boreal forest.

\section{Flight Periods and Possible Origins}

In southern Ontario, immigrant Buckeyes arrive in June, their progeny emerge in late July, and the flight period extends to early October, with a possible late brood emerging in September. ${ }^{3}$ Some July specimens from older records in Manitoba show signs of wear, and they are possibly immigrant adults originating in the northern United States.

Based on wing appearance, the late June and early July 2001 specimens from the Rice River Road were freshly emerged. They had evidently either originated at the collection site or very recently arrived from sites close by. They may have been offspring of immigrant adults that could have laid eggs in May. It is unlikely that they represent a local resident population, given what is known of the species' distribution and habits.

The specimens collected in the Spruce Woods-Shilo region in 2007 where not particularly worn but certainly not freshly emerged; they may well have originated in the Dakotas. Twenty plots in this region were sampled twice a week from mid-June to late August, and it is unlikely that the species would have been overlooked, if present in any numbers, before the two late-July records.

One of the two individuals seen near Pinawa on 3 October 2007 was in immaculate condition, suggesting local emergence. The Beaconia, Oak Hammock Marsh, and Patricia Beach butterflies were seen during and immediately after a strong southerly wind on 15 September 2007, thus they may well have originated elsewhere. They appeared only slightly worn, except for damaged wing tips on one of the Oak Hammock Marsh individuals.

\section{Discussion}

A warming climate may dramatically affect the distribution of many organisms, including butterflies. ${ }^{2,6,13}$ For an emigratory insect such as the Buckeye, one might expect more northerly overwintering, emigration, and breeding to occur. At the northern edge of the range, earlier arrival dates, more frequent occurrence of late broods, and longer survival into the fall months would also be predicted. Our recent observations of Buckeye butterflies in Manitoba are consistent with these expectations. The 2001 records along the Rice River Road (see Table 1) were about $200 \mathrm{~km}$ north of the 1976 colony in Sandilands Provincial Forest. ${ }^{7}$ The records compiled in Table 1 expand the flight period to 29 June - 3 October, with a strong possibility of some arrivals as early as May. A cluster of Manitoba records from the 1930s to 1941 , however, suggests a possible periodic pattern, perhaps linked to episodes of drought in the Great Plains states and provinces. 
Occurrence of Buckeyes at their northern range limit is known to be sporadic. For example, at Ottawa, Ontario one specimen was collected in 1966 and one individual was seen in 1996, but a "major invasion" occurred in 1981. Three temporary breeding colonies were formed, and the species was observed for several months at an old gravel quarry where two of the preferred larval food plants, gerardia and toadflax, were abundant. ${ }^{8}$

We hope this article will encourage other naturalists to look for this attractive butterfly in Manitoba and neighbouring regions, and to document any further extensions of its range and flight periods.

\section{Acknowledgements}

We thank R. Mooi for access to Buckeye specimens at The Manitoba Museum, Winnipeg, including the 1994 Winnipeg specimen, and L. Klassen for information on his sightings in 2007.

\section{BUTTERFLIES AND MOTHS OF NORTH} AMERICA website, http://butterfliesandmoths.org. Hosted and maintained by the Big Sky Institute at Montana State University and the NBII Mountain Prairie Information Node.

2. DENNIS, R.L. 1993. Butterflies and Climate Change. Manchester University Press.

3. HOLMES, A.M., Q.F. HESS, R.R. TASKER, and A.J. HANKS. 1991. The Ontario Butterfly Atlas. Toronto Entomologists' Association, Toronto.

4. HOOPER, R.R. 1973. Butterflies of Saskatchewan: A Field Guide. Museum of Natural
History and Saskatchewan Department of Natural Resources, Regina.

5. HOWE, W.H. 1975. The Butterflies of North America. Doubleday \& Co., New York.

6. KERR, J.K. 2001. Butterfly species richness patterns in Canada: energy, heterogeniety, and the potential consequences of climate change. Conservation Ecology, 5(1), Article 10 (available online at www.envirolink.org).

7. KLASSEN, P., A.R. WESTWOOD, W.B PRESTON, and W.B. MCKILLOP. 1989. The Butterflies of Manitoba. Manitoba Museum of Man and Nature, Winnipeg.

8. LAYBERRY, R.A., P.W. HALL, and J.D. LAFONTAINE. 1998. The Butterflies of Canada. University of Toronto Press, Toronto.

9. MYRES, M.T. 1985. A southward return migration of Painted Lady butterflies, Vanessa cardui, over southern Alberta in the fall of 1983, and biometeorological aspects of their outbreaks into North America and Europe. Canadian FieldNaturalist 99:147-155.

10. NELSON, R.W. 1985. Southward migration of Painted Ladies in Alberta and British Columbia. Blue Jay 43:7-15.

11. OPLER, P.A. and G.O. KRIZEK. 1984. Butterflies East of the Great Plains: An Illustrated Natural History. Johns Hopkins University Press, Baltimore.

12. ROYER, R.A. 2003. Butterflies of North Dakota: An atlas and guide (2nd edition). Minot State University Science Monograph series, No. 2.

13. WESTWOOD, R. and D. BLAIR. 2006. Effect of Regional Climate Warming on Forest Pest Management in Boreal Forest Ecosystems Using Butterflies as Indicators of Phenological Change and Shifts of Species Geographic Range. University of Winnipeg, Technical report to Natural Resources Canada, Project A726.

"In the passage from day to night there is to me always something mysterious. In the forest that hour is mournful and sad. Around reigns an oppressive silence. Then the ear just catches some barely audible sound, as though distant sigh. Whence does it come? It seems as though the taiga itself is sighing." V. K. Arseniev, Dersu the Trapper, p. 125. 